\title{
A NEW GENERATION OF CONTROLLED OPTIC SWITCH
}

Mehman Huseyn Hasanov, Azerbaijan Technical University, Baku, Azerbaijan, mhasanovnew@gmail.com

\section{Nadir Bafadin Agayev,}

Azerbaijan Technical University, Baku, Azerbaijan, nadir.agayev@aztu.edu.az

Nadir Arzu Atayev, Azerkocmos" OJSC, Baku, Azerbaijan, nadir_atayev@mail.ru

Vali Muxtar Fataliyev, Azerbaijan Technical University, Baku, Azerbaijan, velif@aztu.edu.az
Manuscript received 21 December 2020;

Accepted 26 January 2021

Keywords: optical switch, microelectromechanical systems, 3D switch, control device, micromotor

Optical switches (OS) are widely used for switching optical signals in optical networks. Parameters and technical characteristics of OS include its capacity, number of inputs and outputs, speed of transition from one state to another, optical losses during signal transmission in the channel (value of attenuation coefficient in "on" state) and switching obstacles or switch off (in "off" state) the value of the extinction coefficient) and so on. The article proposes a new design of a new generation 3D switch based on a comparative analysis with other optical switches to create a high-speed and efficient optical transition in optical networks. The working principle of the proposed 3D switch is explained and a new structural block diagram is developed. The efficiency probability of the elements ensuring the stable operation of the proposed optical switch was calculated, calculations were performed in the MATLAB environment, and graphs of the probability of unrejected operation of the device were constructed.

Information about authors:

Mehman Huseyn Hasanov, Candidate of Technical Sciences, PhD, Department of "Telecommunication systems and information security", Azerbaijan Technical University, Baku, Azerbaijan

Nadir Bafadin Agayev, professor, doctor of Technical Sciences, Department of "Engineering mathematics", Azerbaijan Technical University, Baku, Azerbaijan

Nadir Arzu Atayev, "Azerkocmos" OJSC, electronics engineer, Baku, Azerbaijan

Vali Muxtar Fataliyev, Candidate of Technical Sciences, PhD, Department of Technology Transfer, Azerbaijan Technical University, Baku, Azerbaijan

Для цитирования:

Гасанов М.Г., Агаев Н.Б., Атаев Н.А., Фаталиев В.М. Новое поколение управляемых оптических переключателей // Т-Сотm: Телекоммуникации и транспорт. 202I. Том I5. №3. С. 64-68.

For citation:

Hasanov M.H., Agayev N.B., Atayev N.A., Fataliyev V.M. (2021) A new generation of controlled optic switch. T-Comm, vol. I5, no.3, Pp. 64-68. (in Russian) 


\section{Introduction}

The optical characteristics shown in high-quality OS are considered taking into account the wavelengths and the polarizations of the beam [1-7].

Depending on the principle of operation, optical switches are mainly divided into: mechanical optical switches, electro-optical optical switches, thermooptic optical switches, integrated-optical switches, semiconductor optical switches, optical switches with photon crystals and multilayers of liquid crystals [1, 5, 7].

The technical characteristics of modern optical switches differ significantly from each other. For example, in mechanical switches, the switching time is from $10 \mathrm{~ms}$ to $500 \mathrm{~ms}$, the losses are approximately $0.5 \mathrm{~dB}$, the switch-off is up to $30 \mathrm{~dB}$, and the number of input and output ports is from 50 to 1600. In electrooptical OKs, the operating speed is 10-100ps (significantly higher), but their capacities are usually small, for example, 1x2 and $2 \times 2$. When several of these OS are connected in series, their component capacities increase. In recent years, microelectromechanical system and switches (MEMS) have begun to attract the attention of manufacturers of optical switches. Technologies such as microelectronics as well as integrated optics are widely used in this type of switches [1-7].

The purpose of the work is to create a new 3D switch based on the analysis of the parameters of optical-photon switches, the principles of construction and to determine the probability of uninterrupted operation of the 3D optical switch.

\section{D switch}

Based on the analysis of MEMS-type micromechanical switches widely used for their functionality a new generation 3D optical switch of MEMS type has been developed (Fig.1). Figure 1 shows the mechanical design scheme of the 3D design model of the 3D optical switch.

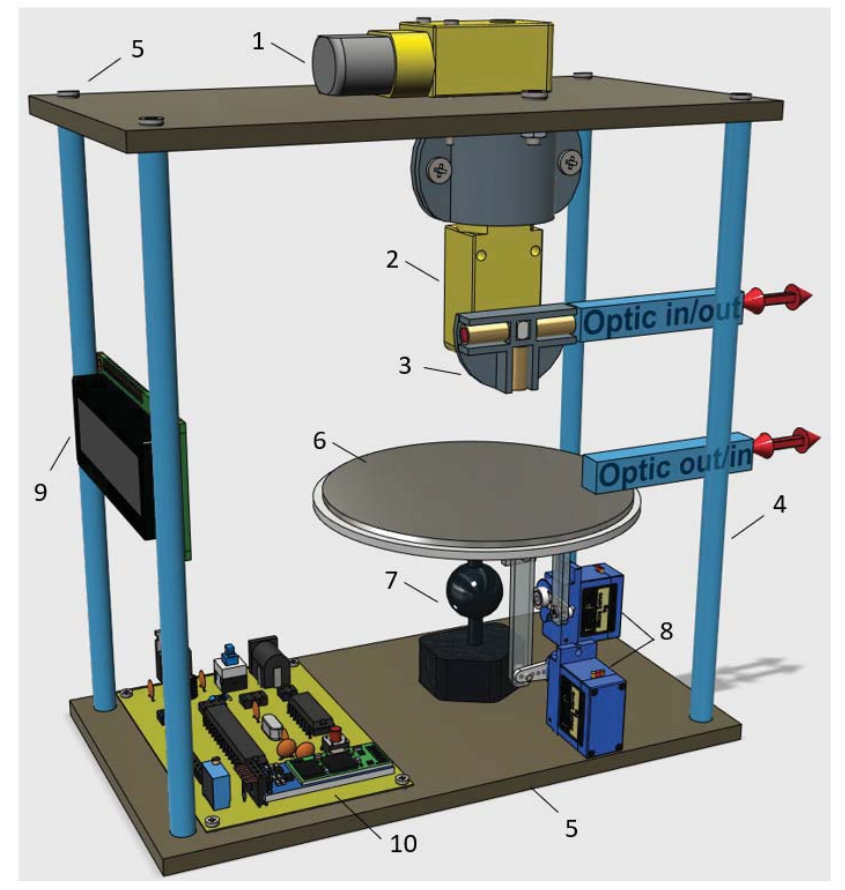

Figure. 1. Mechanical design of the 3D design model of a 3D optical switch
As shown in Figure 1. 1, 2 - micromotors, 3 - laser/LED head that provides input/output to the optical channel, 4 - supports that hold the upper and lower platform together, 5 - upper and lower platform areas, 6 - semi-transparent mirror platform (MP) that directs laser beams in the required direction to the optical output/input, 7 - joint, 8 - micromotor that provides movement of MP, 9 - LCD screen showing the status of micromotors and laser/LED, 10 - consists of an electronic board of the automatic control system and other auxiliary parts. Structural block diagram illustrating the working principle of a 3D optical switch is shown in Figure 2.

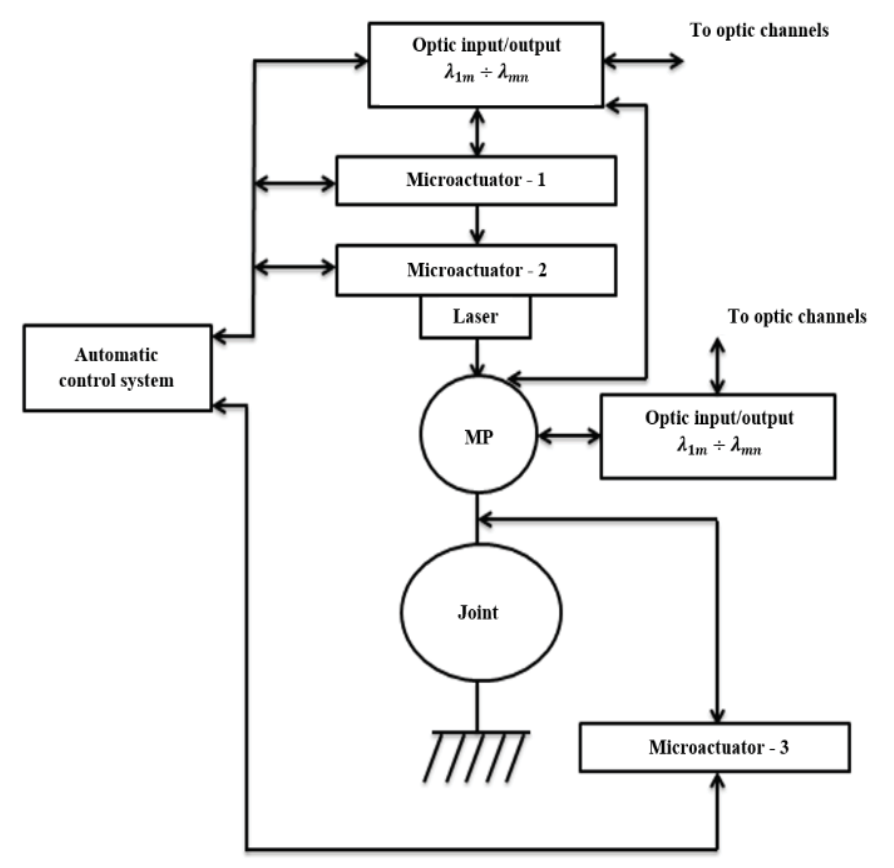

Figure. 2. Structural block diagram of a 3D optical switch

\section{Optical switch control}

In the new model of the presented optical switch, the micromotor- 1 provides 360 degrees central axis rotating system for the micromotor-2. According to the control program for the system, micromotors 1 and 2 are controlled and directs the optical signals coming from the optical input / output channel to the MP via a directional laser head. The mirror panel is made in the form of a matrix, and each matrix is calculated on one of the wavelengths of $\lambda_{1 n} \div \lambda_{m n}$ and the optical signals separated by wavelengths in different vertical and horizontal directions are directed to the input/output of optical channels. The reverse process is carried out according to the same rule [1-7]. In order to increase the switching speed of the channels, a MP is placed on the 7 - joint to reduce the switching time and direct the optical beam to the optical input/output via the micromotor-3 to direct the channel for switching. The control of all situations of the optical switching environment is displayed on the LCD screen, instead of the LCD screen via a USB port or Bluetooth modules from other computer terminals, etc. can be used. All micro-motors are controlled by the 10 -automatic control system, which provides software and operation of the device through the feedback circuit. 
Since the initial prototype of the new generation 3D switch was assembled, $80 \%$ of the materials used were made by hand using a composite composition, and 20\% were printed and tested by a 3D printer.

The new generation 3D optical switch prototype has the following advantages compared to other MEMS type optical switches:

- Compact assembly of lenses, depending on the number of beam sources, the arrangement of light sources in one way or another on a 360 degree rotation head, thereby reducing the size, amount of material consumed and the financial cost of the final device;

- Multiply the switching time of the incoming optical signals by controlling the laser heads in the final device via two high-precision microactuators and by controlling the movement of the translucent mirror in the switching direction;

- Possibility for constant control of the switch and effective diagnostics of the problems through the integrated electronic control and measuring system.

\section{Determination of the probability of unrejection operation of a 3D optical switch}

Assume that all the active elements of the 3D optical switch shown in Figure 2 belong to non-recoverable systems [8]. Let us denote the probability of unrejected operation of the elements by generalizing similar elements (micromotors) from $P_{1}$ to $P_{8}$. Here let's take $P_{1}$ as - automatic control, $P_{2}$ as - optical input/output, $P_{3}$ as - micromotor $1, P_{4}$ as - micromotor $2, P_{5}$ as - MP, $P_{6}$ as optical output/input, $P_{7}$ as - joint, $P_{8}$ as probability of unrejected work of 3rd micromotor. If we denote the probability of continuous operation of each element in time t by $P_{i}(t), i=\overline{1,8}$ and the intensity of rejection by $\lambda_{i}(t), i=\overline{1,8}$.

$$
P_{i}(t)=e^{-\int_{0}^{t} \lambda_{i}(\tau) d \tau}, i=\overline{1,8}
$$

then this can be written for each element $[9,10]$. This will be the case if the rejection intensity of the elements is constant

$$
\lambda_{i}(t)=\lambda_{i}=\text { const }
$$

and in this case

$$
P_{i}(t)=e^{-\lambda_{i} t}, i=\overline{1,8}
$$

it will be written as formula (1).

According to Scheme 2, we can write for the probability of unrejection operation of the device as a whole $-P(t)$ according to the method of connection of each element in the device.

$$
\begin{aligned}
& P(t)=\left[1-P_{1}(t) \cdot P_{7}(t) \cdot P_{8}(t)\right] \cdot\left[1-P_{1}(t) \cdot P_{5}(t)\right] \times \\
& \times\left[1-\left(1-P_{2}(t)\right) \cdot\left(1-P_{3}(t)\right) \cdot(1-P(t)) \cdot\left(1-P_{2}(t) \times\right.\right. \\
& \left.\left.\times P_{3}(t)\right) \cdot\left(1-P_{2}(t) \cdot P_{4}(t)\right)\right] \cdot\left[1-\left(1-P_{6}(t)\right) \cdot\left(1-P_{7}(t)\right) \times\right. \\
& \left.\times\left(1-P_{7}(t) \cdot P_{8}(t)\right)\right]
\end{aligned}
$$

In this case, it will be calculated as the average time of unrejection operation of the proposed device.

$$
T_{c}=\int_{0}^{\infty} P(\tau) d \tau
$$

The work case of unrejection dispersion will be calculated as follows:

$$
D_{c}=2 \int_{0}^{\infty} \tau P(\tau) d \tau-T_{c}^{2}
$$

It will be calculated as the probability of unrejection operation of the device in a limited time interval $\left(t_{1}, t_{2}\right)$.

$$
P\left(t_{1}, t_{2}\right)=\frac{P\left(t_{1}\right)}{P\left(t_{2}\right)}
$$

There will be a probability of unrejection operation of the device within the (3) condition.

$$
\begin{aligned}
& P(t)=\left[1-e^{-\left(\lambda_{1}+\lambda_{7}+\lambda_{8}\right) t}\right] \cdot\left[1-e^{-\left(\lambda_{1}+\lambda_{5}\right) t}\right] \times \\
& \times\left[1-\left(1-e^{-\lambda_{2} t}\right) \cdot\left(1-e^{-\lambda_{3} t}\right) \cdot\left(1-e^{-\lambda_{4} t}\right) \cdot\left(1-e^{-\left(\lambda_{2}+\lambda_{3}\right) t}\right) \times\right. \\
& \left.\times\left(1-e^{-\left(\lambda_{2}+\lambda_{4}\right) t}\right)\right] \cdot\left(1-\left(1-e^{-\lambda_{6} t}\right) \cdot\left(1-e^{-\lambda_{7} t}\right) \times\right. \\
& \left.\times\left(1-e^{-\left(\lambda_{7}+\lambda_{8}\right) t}\right)\right]
\end{aligned}
$$

If we assume that all elements have the same rejection intensity, $\lambda_{i}=\lambda, i=1,8$. Then formula (8) will be simplified to show the following:

$$
\begin{aligned}
& P(t)=6 \cdot e^{-2 \lambda t}-2 \cdot e^{-3 \lambda t}-22 \cdot e^{-4 \lambda t}+11 \cdot e^{-5 \lambda t}+29 \cdot e^{-6 \lambda t}- \\
& -14 \cdot e^{-7 \lambda t}-23 \cdot e^{-8 \lambda t}+e^{-9 \lambda t}+26 \cdot e^{-10 \lambda t}-23 \cdot e^{-12 \lambda t}+ \\
& +9 \cdot e^{-13 \lambda t}+6 \cdot e^{-14 \lambda t}-5 \cdot e^{-15 \lambda t}+e^{-16 \lambda t}
\end{aligned}
$$

If we take into account the formula (9) in (5), the average duration of the unrejected operation of the proposed device of the variance of the unreject operation is:

$$
T_{c}=\frac{0,636}{\lambda}
$$

The work case of unrejection dispersion will be:

$$
D_{c}=\frac{1,047}{\lambda^{2}}
$$

\section{Computational experiment}

Assume that all elements of the device have the same unrejected service life. The experiment is conducted for two cases: in the first case, the unrejected service life of the elements is assumed to be 10 years (Figure 3), and in the second case, 15 years (Figure 4$)$.

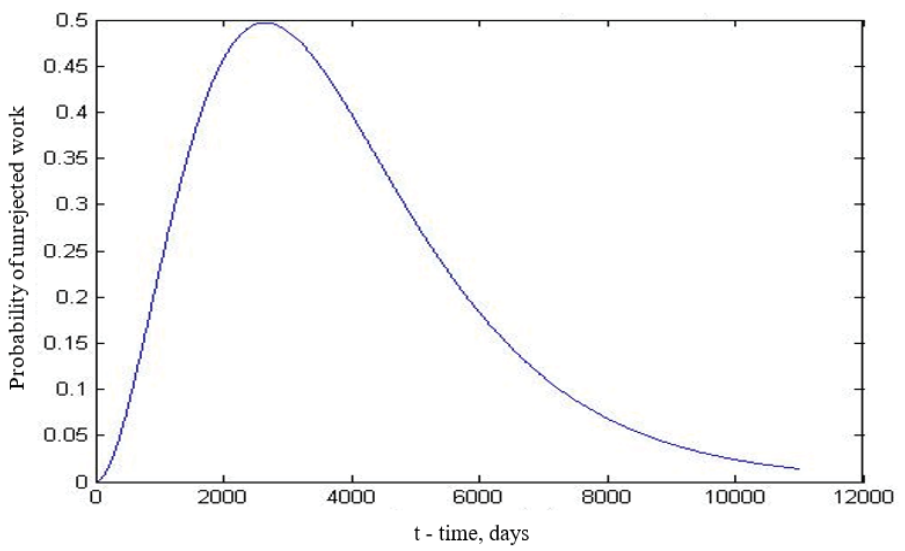

Figure 3. Graph of the probability of unrejected operation of the device when the warranty period of the elements is 10 years 
As can be seen from Figure 3, the probability of unrejected operation of the system increases until the average service life of the elements and reaches its maximum value of 0.5 . Increasing the unrejected operation time of the elements (Figure 4) does not affect the maximum probability of unrejected operation. Since the process of continuous operation for each element occurs with the same constant rejection intensity, the reliability of the system will vary only depending on the method of combining these elements.

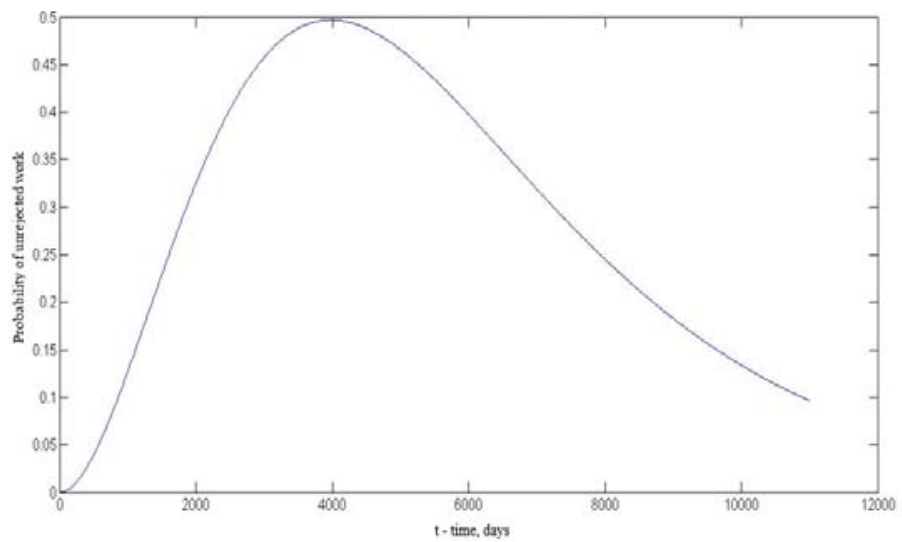

Figure 4. Graph of the probability of unrejected operation of the device when the warranty period of the elements is 15 years

The maximum value of the probability will change when the unrejected work time for the elements is taken differently, but the nature of the curve will not change (Figure 5).

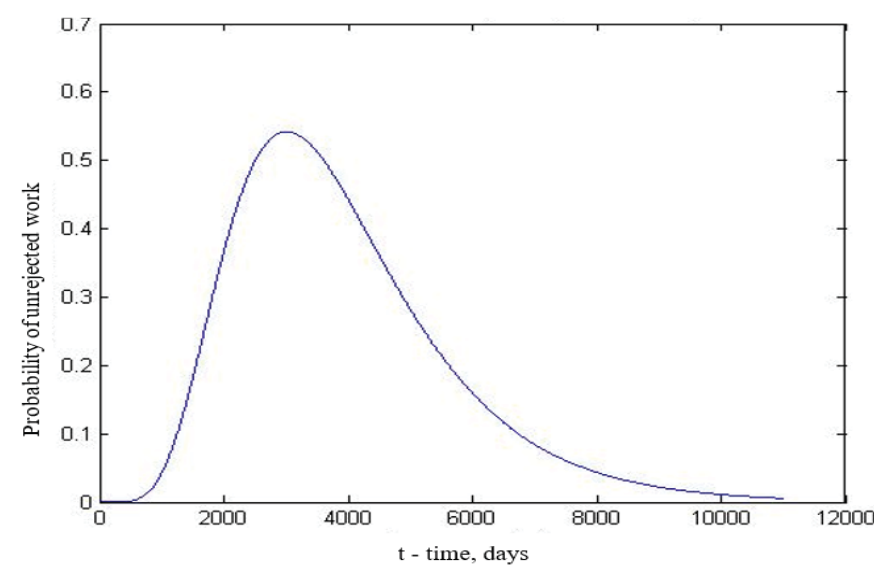

Figure 5. Graph of the probability of unrejected operation of the device when the warranty period of the elements is 15 years
Here the average unrejected service life of micromotors ( $T 3=T 4=T 8=5$ years), for optical input-output and outputinput ( $T 2=T 6=8$ years); for $\mathrm{MP}$ ( $T 5=6$ years $)$, for joint ( $T 7=8$ years) and for automatic control system $(T 1=10$ years). Calculations show that in this case, the maximum value of the probability of unrejected operation of the system is relatively different from the case when the reliability of the elements is the same. This confirms the above idea: the unrejected operation time of the system depends more on the method of their integration in the system than on the uninterrupted operation time of the elements separately.

\section{The result}

As a result of the analysis of optical switches used for switching channels in modern optical transmission systems, the first model of the new generation 3D switch and the block diagram of the operating mode is presented in the article. Taking into account the elements of the block diagram, the probability of the elements that ensure the stable operation of the proposed optical switch was calculated, and the probability of unrejected operation was plotted using the matlab environment. The application of MEMS type 3D optical switch is designed for switching channels in optical transmission systems.

\section{References}

1. M.H. Hasanov. Photon switch of full optical networks. T-Comm. No. 8. 2019. Vol. 13. P. 47-51.

2. Q.S. Gaivorovskaya, A.B. Ryabtsov. Features of the use of optical switches in modern information networks. Applicable Information Models. Sofia. ITHEA, 2011. No. 22. P. 169-181.

3. M.H. Hasanov. Multi-channel piezoelectric switch adapter for optical networks. Bulletin of the Azerbaijan Academy of Engineering. Vol. 9. No. 4. 2017. P. 107-113.

4. Mehman H. Hasanov, Konul R. Hajiyeva, Shalala F. Godjaeva. Multifunctional adaptive piezoelectric switch of optical channels. T-Comm. Vol. 13. No. 9. 2018.

5. Vladimir Makkaveev. Photon switches. Components and Technologies. P. 142-146. No. 2. 2006.

6. E.A. Barabanova. Optical two-stage switching system for processing large volumes of data. Informatics, Computer Engineering and Management. NGTU Scientific Bulletin. Vol. 70. No. 1, 2018. P. 7-18.

7. A.V. Ryabtsov. Piezooptic scanning switches. Information Theories and Applications. Vol. 20. No. 3. 2013. P. 295-299.

8. E.V. Dzirkal. Assignment and verification of requirements for complex products. Moscow: Radio and communication. 1981. $176 \mathrm{p}$.

9. S.G. Konesev, R.T. Khazieva. Methods of assessment of indicators of reliability of complex components and systems. Modern problems of science and education. 2015. No. 1-1; URL: http://www.science-education.ru/ru/article/view?id=17558.

10. H.A. Severtsev. Theory of reliability of complex systems in development and operation: textbook. allowance for academic bachelor. 2nd ed., Moscow: Yurait Publishing House, 2018. 435 p. (Series: Bachelor. Academic Course). ISBN 978-5-534-07531-1. 


\section{НОВОЕ ПОКОЛЕНИЕ УПРАВЛЯЕМЫХ ОПТИЧЕСКИХ ПЕРЕКЛЮЧАТЕЛЕЙ}

Мехман Гусейн оглы Гасанов, Азербайджанский Технический Университет, г. Баку, Азербайджан, mhasanovnew@gmail.com

Надир Бафадин оглы Агаев, Азербайджанский Технический Университет, г. Баку, Азербайджан, nadir.agayev@aztu.edu.az

Haдup Арзу оглы Amaе6, "Azerkocmos" OJSC, г. Баку, Азербайджан, nadir_atayev@mail.ru

Вели Мухтар оглы Фаталиев, Азербайджанский Технический Университет, г. Баку, Азербайджан, velif@aztu.edu.az

\section{Аннотация}

Предлагается новая конструкция 3D-коммутатора нового поколения на основе сравнительного анализа с другими оптическими коммутаторами для создания высокоскоростного и эффективного оптического перехода в оптических сетях. Объясняется принцип работы предлагаемого трехмерного переключателя и разработана новая структурная блок-схема. Рассчитана вероятность работоспособности элементов, обеспечивающих стабильную работу предложенного оптического переключателя, проведены расчеты в среде MATLAB и построены графики вероятности безотказной работы устройства. В результате анализа оптических переключателей, используемых для переключения каналов в современных системах оптической передачи, в статье представлена первая модель 3D-переключателя нового поколения и структурная схема режима работы. С учетом элементов блок-схемы рассчитана вероятность наличия элементов, обеспечивающих стабильную работу предлагаемого оптического переключателя, и построена вероятность безотказной срабатывания в среде Matlab. Применение оптического переключателя 3D типа MEMS предназначено для переключения каналов в системах оптической передачи.

Ключевые слова: оптический переключатель, микроэлектромеханические системы, 3D-переключатель, устройство управления, микромотор.

\section{Литература}

I. Hasanov M.H. Photon sw?tch of full opt?cal networks. T-Comm. Telecommunications and transport 8/2019, vol. 13, no.8, pp. 47-5I.

2. Гайворовская Г., Рябцов А.В. Особенности применения оптических коммутаторов в современных информационных сетях. Applicable Information Models. Sofia. ITHEA, 20II. №22. pp. 169-I8I.

3. Гасанов М.Г. Многоканальный пьезоэлектрический коммутатор адаптивных оптических сетей. Вестник Азербайджанской Инженерной Академии. Том 9, №4. 2017. с. 107-II3.

4. Mehman H. Hasanov, Konul R. Haciyeva, Shalala F. Qodjaeva. Multifunctional adaptive piezoelectric switch of optical channels. T-Comm: Телекоммуникации и транспорт. Том 13, № 29. 2018.

5. Владимир Маккавеев. Фотонные коммутаторы. Компоненты и Технологии. № 2, 2006. С. I42-I46.

6. Барабанова Е. А. Оптическая двухкаскадная коммутационная система для обработки больших объемов данных. Информатика, Вычислительная Техника и Управление. Научный вестник НГТУ. Том 70, № I, 2018. С. 7-18.

7. Рябцов А.В. Пьезооптические сканирующие коммутаторы. Information Theories and Applications, Vol. 20. No. 3, 2013. P. $295-299$.

8. Дзиркал Э.В. Задание и проверка требований к надежности сложных изделий. М.: Радио и связь. 198 І. 176 с. (Б-ка инженера по надежности).

9. Конесев С.Г., Хазиева Р.Т. Методы оценки показателей надежности сложных компонентов и систем // Современные проблемы науки и образования. 20I5. № I-I. URL: http://www.science-education.ru/ru/article/view?id=I7558.

10. Севериев Н.А. Теория надежности сложных систем в отработке и эксплуатации: учеб. пособие для академического бакалавриата. 2-е изд., перера6. и доп. М.: Издательство Юрайт, 2018. 435 с. (Серия: Бакалавр. Академический курс). ISBN 978-5-534-0753I-I.

Информация об авторах:

Мехман Гусейн оглы Гасанов, к.т.н., доцент кафедры "Телекоммуникационные системы и информационные безопасности", Азербайджанский Технический Университет, г. Баку, Азербайджан

Надир Бафадин оглы Агаев, д.т.н., профессор кафедры "Инженерная математика" Азербайджанский Технический Университет, г. Баку, Азербайджан

Надир Арзу оглы Aтаев, "Azerkocmos" OJSC, инженер электронщик, г. Баку, Азербайджан

Вели Мухтар оглы Фаталиев, к.т.н., Департамент трансфера технологий, Азербайджанский Технический Университет, г. Баку, Азербайджан 